\title{
STAFF TRAINING AND DEVELOPMENT: A COMPARATIVE ANALYSIS OF NATIONAL HOTELS IN SERBIA AND INTERNATIONAL HOTEL CHAINS***
}

\begin{abstract}
Having a qualified and trained workforce is an imperative for operating in the hotel management and tourism industry. Companies should show they care about their employees by giving them opportunities for promotion and development. The aim of this paper is to compare the staff training and development programs in the national hotels in Serbia with programs in international hotel chains. In order to achieve a predefined goal, we used the method of comparative analysis. Data for analysis were collected by researching the existing literature, the official hotel websites and interviewing managers in national hotels in Serbia. The results indicate that the staff training and development programs are more advanced in the international hotel chains. Management in the national hotels in Serbia is determined to follow different staff training and development programs. However, they should invest more in establishing more programs, especially those aimed at their staff's development which they can copy from the international hotel chains. The results of this research can be useful to hotel managers in the creation process of their own innovative staff training and development programs.
\end{abstract}

Keywords: human resource, training and development, comparative analysis, national hotels in Serbia, international hotel chains.

* MSc, Junior Researcher, University of Kragujevac, Faculty of Hotel Management and Tourism in Vrnjačka Banja; irena.celic994@gmail.com

* Ph.D., Associate Professor, University of Kragujevac, Faculty of Hotel Management and Tourism in Vrnjačka Banja; snezana.milicevic@kg.ac.rs

*** MSc, Teaching Assistant, University of Kragujevac, Faculty of Hotel Management and Tourism in Vrnjačka Banja; natasa.djordjevic@kg.ac.rs

**** The paper is a result of research within the projects 179066 and III 46006, funded by the Ministry of Education, Science and Technological Development of the Republic of Serbia. 


\section{Introduction}

Today, companies are expected to adapt their businesses to the current industry trends. In fact, to evolve over and over. ${ }^{1}$ The changes in different spheres of business encourage hotel companies to constantly invest in their staff. For instance, because of bigger and more frequent technological changes, companies need to acquire new and broaden the existing knowledge. ${ }^{2}$ During this process, hotel management should remember that technical equipment, interior design, or products aren't the foundation of hotels - they can all be replaced or recreated. Their foundation is a qualified staff. ${ }^{3}$ In order for companies to develop and retain that qualified staff, they need to have Human Resources (HR) department. The managers who work in this position can increase the number of qualified staff by exposing them to the training and development process. Staff training becomes a crucial principle for good management if it is carried out constantly.

The goal of this paper is to compare the staff training and development programs in the national hotels in Serbia with the international hotel chains.

\section{Theoretical backgrounds}

\subsection{Staff training and development in the hospitality industry}

The process of employee training is a long-term investment for every company. ${ }^{5}$ The importance of staff training has increased on a global scale. ${ }^{6}$ Employees can go through trainings for their technical knowledge, communication skills, conceptual skills, professional skills, customer care, sale and marketing, and

1 Tošović-Stevanović Aleksandra, Ana Jurčić, Mihajlo Rabrenović. (2017): „Kulturološki aspekti menadžmenta i njihov uticaj na konkurentnost zemalja “. Megatrend Review, Vol. 14, No. 3, 149-164.

2 Savović, Slađana. (2006): “Značaj obuke i razvoja kadrova u ostvarivanju konkurentske prednosti preduzeća."Ekonomski horizonti, Vol. 8, No. 1-2, 49-58.

3 Milićević Snežana, Štetić Snežana. (2017): Menadžment u turizmu, Vrnjačka Banja: Fakultet za hotelijerstvo i turizam.

$4 \quad$ Vukonjanski Igor. (2019): Significance and successful training of persons in public administration of selected lands. Megatrend revija, Vol. 16, No. 3, 115-131.

5 Ameeq-ul-Ameeq, HanifF. Furqan. (2013): “Impact of Training on Employee's Development and Performance in Hotel Industry of Lahore, Pakistan." Journal of Business Studies Quarterly, Vol. 4, No. 4, 68-82.

$6 \quad$ Poór József, Slavić Agneš, Katalin Tóth, Berber Nemanja, Kerekes Kinga, Karoliny Zsuzsa. (2020): „Benchmarking in human resource management in focus of Central and Eastern Europe in the light of CRANET research." Strategic Management, Vol. 25, No. 1, 21-28. 
health and safety measures. ${ }^{7}$ Perović $(2007)^{8}$ and Milićević \& Štetić (2017) ${ }^{9}$ stress that the basic goal of the training process is to get employees to independently perform their jobs. During this process, those employees acquire new skills and knowledge that will help them fulfill business' set goals. Also, employees start to understand that there are consequences if those goals aren't achieved (e.g. consequences for the individuals, all employees, or the whole company).

Staff training is extremely important ${ }^{10}$ and it has become the key for a company's success, especially now that there is fierce competition. ${ }^{11}$ The staff training programs should be an integral and implemented part of a company's strategy. ${ }^{12}$ Amin et al. (2017) ${ }^{13}$ suggest that companies should develop the training programs if they determine there is the need for them. A huge number of companies in the European Union (EU) use data estimates (of the current situation, achieved results, etc.) to identify the needs and reach important decisions about training and development (e.g. who should be trained and for how long, which methods should they use, what their goals are). According to the International Network of Business Schools that researches human resource management, a whopping $74 \%$ of the total number of companies in the EU bases their decisions about training and development on these data estimates (Cranet, 2020). The percentage differs from country to country. It's 95\% in Indonesia, 94.9\% in Switzerland, 70\% in Israel, almost 70\% in Serbia, and 51.6\% in Norway.

Afaq et al. $(2011)^{14}$ suggest that training is important in the hospitality industry. Also, they state that these training programs are designed to teach new skills to employees to help them meet the needs of the consumers. One of the benorganizations." Hotel and Tourism Management, Vol. 7, No. 2, 115 - 125.

8 Perović J. Milan. (2007): “Obuka i osposobljavanje u funkciji integrisanog sistema menadžmenta.” 34. Nacionalna konferencija o kvalitetu, Kragujevac, 08. - 11. maj, uvodni referat.

9 Milićević Snežana, Štetić Snežana. (2017).

10 Rathore Pradyuman Singh. 2017. „Significance of training and hospitality skills for hotel employees." International Journal of Engineering and Management Research (IJEMR), Vol. 7, No. 3, 53-56.

11 Ristić Miroslava, Radovanović Ivica, Tadić Aleksandar. (2011): “Obuka zaposlenih u sistemu e-učenja.”Inovacije u nastavi - časopis za savremenu nastavu, Vol. 24, No. 3, 74-85.

12 Slavić Agneš. (2005): "Obuka zaposlenih - značaj i uticaj na postizanje strategijskih ciljeva preduzeća.” Strategijski menadžment,” Vol. 10, No. 3, 29-34.

13 Amin Muslim, Aldakhil Abdullah Mohamed, Wu Chengzhong, Rezaei Sajadand, Cobanoglu Cihan. (2017): “The structural relationship between TQM, employee satisfaction and hotel performance", International Journal of Contemporary Hospitality Management, Vol. 29, No. 4, 1256-1278.

14 Afaq Fakhar Ul, Yusoff Rosman, Khan Anwar, Azam Kamran, Thukiman Kassim. (2011): Employees' training and performance relationship in hospitality sector-A case of pearl continental hotel, Karachi, Pakistan. International Review of Business Research Papers, Vol. 7, No. 3, 149-158. 
efits of the training and development programs in the hospitality industry is the opportunity for teamwork between employees and management. ${ }^{15}$ A case study conducted in Nigeria's hospitality industry shows that training affects employee motivation and performance. ${ }^{16}$ In addition, one research done in the hotels in Dubrovnik (Croatia) shows employee training was neglected which negatively affected their performances. ${ }^{17}$ Afaq et al. $(2011)^{18}$ believe that those employed in hotels that devote more time to training have better performances. Muthukumar et al., (2016) ${ }^{19}$ emphasize that employees won't quit if hotel companies offer good and quality training programs.

Apart from the training, employees should have proper growth and development programs. Olabinjo, Ezenagu \& Esoso (2020) ${ }^{20}$ write that employee development refers to the activities whose goal is to preserve or improve employees' competencies, skills, and abilities so they could carry out their jobs. This can be achieved through educational programs, incentive programs, seminars, and workshops. In the Best Western International Hotels, employees have an opportunity to grow and develop in prestigious universities while getting suitable financial aid. ${ }^{21}$

\subsection{Staff training and development methods in the hospitality industry}

Hotel companies can employ different methods to train or develop their employees. The programs need to be practical and well-thought-out to be successful or to effectively teach new skills. ${ }^{22}$ Today, managers view training as a

15 Mohan Ajeet Kumar Lal, A. Dharmaraj. (2015): "Training-an imperative hr practice in hotel industry." International Journal of Physical and Social Sciences, Vol. 5, No. 12, 96-103.

16 Habib Ahsan, Shahadat Hossain, David Daniel Essien. (2016): "Assessing the Effect of Training on Employees' Performance in Nigeria Hotel Industry: A Case Study of Sheraton Hotel and Resorts Lagos." Singaporean Journal of Business, Economics and Management Studies, Vol. 51, No. 3785, 1-13.

17 Komenić Pavle, Vanda Bazdan, Besim Agušaj. “The organizational climate and employee turnover Intention in Dubrovnik hotels.” RIThink Vol. 5, No. 1, 7-14

18 Afaq Fakhar Ul, et al., 149-158.

19 Muthukumar E., Vidhya Shanmugam, Babu Jiby. (2016): "Effectiveness \& evaluation of training and development programme in Pollachi hotels - a case study." Journal of Arts, Science \& Commerce, VII - Vol. 3, No. 2, 1-7.

20 Olabinjo, M.A., Ezenagu Ngozi, Esoso, J. (2020): Appraisal of hospitality industry's response to human resource management issues and challenges: Evidence from Lagos, Nigeria African Journal of Hospitality, Tourism and Leisure, Vol. 9, No. 2, 1-19.

21 Živković Radmila, Aleksić Ana, Gajić Jelena. (2014): "Razvijanje kompetencija zaposlenih u hotelijerstvu." HR konferencija: Upravljanje kvalitetom ljudskih resursa - savremeni trendovi, Beograd, 23. oktobar, 109-116.

22 Rakičević, Gabriela. (2000): „Obrazovanje - investicija u ljudski kapital. “ Turizam, No. 4, 41-43. 
lifestyle and another business activity that uses either formal or informal training methods. ${ }^{23}$

If we were to examine where the training takes place, according to Ameequl-Ameeq \& Hanif $(2013)^{24}$, Milić $(2011)^{25}$, Prasanth $(2015)^{26}$ and Rathore (2017) ${ }^{27}$ there are two basic training types - on- and off-site (e.g. in the institutions or educational centers). Most often Milićević \& Štetić $(2017)^{28}$ uses the internal (teachings, job rotations, etc.) and external methods of employee training (courses, seminars, specialization, education, etc). What's more, Cerović (2019) ${ }^{29}$ writes in more depth about the training types according to where they take place. He states that this criterium entails on-the-job training, outdoor training, and off-the-job training: On-the-job training: the instructions from an internal or external expert; passing professional exams; training with the help of an external institution; training that entails working on different workplaces during the office hours; job rotation; the help of a manager. Outdoor training: written materials; video tapes; extensive use of telecommunication to watch training programs of other institutions. Off-the-job training: formal lectures; simulation; role play. ${ }^{30}$

Prasanth $(2015)^{31}$ state that there are many different training and development methods: on-the-job training, informal training, classroom training, internal training courses, external training courses, on-the-job coaching, life coaching, mentoring, training assignments and tasks, skills training, product training, technical training, behavioral development training, role playing and role-play games and exercises, attitudinal training and development, etc. Furthermore, Đorđević-Boljanović $(2018)^{32}$ mentions that the most frequent staff training methods include: job rotation, on-the-job training, mentorship, informal education, lectures, courses and seminars, simulations, methods based on technology,

${ }_{23}$ Starc, Jasmina, Rodica, Barbara, and Konda, Iva. 2014. "Training and Educating Managers in Tourism." Hotel and Tourism Management, Vol. 2, No. 2, 7-21.

24 Ameeq-ul-Ameeq, Hanif, F. Furqan. (2013): "Impact of Training on Employee's Development and Performance in Hotel Industry of Lahore, Pakistan." Journal of Business Studies Quarterly, Vol. 4, No. 4, 68-82.

25 Milić Zoran. (2011): Menadžment ljudskih resursa, Beograd: Visoka strukovna škola za preduzetništvo.

26 Prasanth, S. (2015): “Training and Development in Hotel Industry." Shanlax International Journal of Management, Vol. 3, No. 1, 27-34.

27 Rathore Pradyuman Singh. (2017). 53-56.

28 Milićević Snežana, Štetić Snežana. (2017). 71.

29 Čerović Slobodan. (2019): Upravljanje ljudskim resursima u hotelijerstvu. Beograd: Univerzitet Singidunum, 176.

30 Ibid.

31 Prasanth S. (2015). 30.

32 Đorđević-Boljanović Jelena. (2018): Menadžment ljudskih resursa. Beograd: Univerzitet Singidunum, 145-149. 
distant learning, videoconferencing, computer-backed training, company's web portals, and the internet.

Around the world, hotel companies devise their own staff training and development programs. These methods are based on theoretical knowledge. A research conducted in Russia's hotel market shows there are developed systems for staff training. ${ }^{33}$ Bourdoukou \& Evangelia $(2020)^{34}$ researched staff training and development in the Cyclades, Greece. They write that most employees in a hotel go through informal and formal training in the workplace. Also, it has been observed that employees want their trainer to be communicative, calm, patient, and friendly during training. A case study made in Ga East Municipality in Ghana shows that the most popular training methods are orientation training, job rotation, demonstrations and examples. The least popular methods are vestibule training, lecture and case study. ${ }^{35}$ Another study carried out in Pollachi, India indicates that trainings are developed according to the goals and needs of the company. The training programs are focused on food production, food and beverage service, front office, and housekeeping. ${ }^{36}$

One advice for those who organize and provide training is to use various training methods ${ }^{37}$, to achieve organizational goals and produce the best results. Although hotels have different opportunities for training Lee \& Bugler (2017) ${ }^{38}$ believe that bosses and managers still prefer the on-the-job training. The benefit of the on-the-job training is that employees gain practical knowledge and confidence because they're trained in the real environment. ${ }^{39}$ The advantages of this training are numerous: higher productivity, lower staff turnover, higher salaries,

33 Dzhandzhugazova A. Elena, Zaitseva A. Nataliya, Larionova A. Anna., Pervunin, N. Sergey. (2015): "The Russian Hotel Market: condition and development under the crisis."Mediterranean Journal of Social Sciences, Vol. 6, No. 3-S5, 289-296.

34 Bourdoukou Aikaterini, Evangelia N. Markaki. (2020): “The Connection Between the Employee Satisfaction and the Learning and Development Process in the Greek Toursim Industry: A Qualitative Analysis." Education and Social Sciences Conference Business and Economics Conference, Barcelona, Spain, 10 February 2020. 41-50.

35 Armah-Ansah, Quartey Rita. (2019): "Effects of Training on Employee Performance in Ga East Hotels". Acta Scientific Paediatrics, Vol. 2, No. 7, 02-07.

36 Muthukumar E., Vidhya Shanmugam, Babu Jiby. (2016): "Effectiveness \& evaluation of training and development programme in Pollachi hotels - a case study." Journal of Arts, Science \& Commerce, VII - Vol. 3, No. 2, 1-7.

37 Martin Ostrowski Barbara, Kolomitro Klodiana, Lam, C. M. Tony. (2014): „Training methods: A review and analysis. "Human Resource Development Review, Vol. 13, No. 1, 11-35.

$38 \quad$ Lee C. Patrick, Bugler R. Martin. (2017): “Training practices in the Hong Kong hotel industry: Managerial and executive perspectives." Journal of Human Resources in Hospitality \& Tourism, Vol. 16, No. 1, 88-107.

39 Vasanthi S., Basariya S. Rabiyathul. (2019): "On the job training implementation and its benefits." IJRAR, Vol. 6, No. 1, 210-215. 
higher motivation and satisfaction among employees, and bigger commitment to the company. ${ }^{40}$

\section{Research Methodology}

In accordance with the set goal, we analyzed both primary and secondary data. The analysis was performed between March and May of 2020 by the public domain benchmarking and one-to-one benchmarking methods. The paper's assumption is that the training and development programs in the international hotel chains are more advanced compared to the programs in the national hotels in Serbia.

We analyzed four international hotel chains - the InterContinental Hotel Group (IHG), Marriott International, the Accor Hotels, and Hyatt. We used the data from these hotels' websites to analyze their training and development programs. Moreover, for Serbia, we selected the following companies - the Mona Hotel Management (the Zlatibor Mona Hotel, Mona Plaza in Belgrade, the Argo Garni Hotel in Belgrade, and the Javor Hotel in Kušići), the Moskva Hotel in Belgrade, the Solaris Resort Hotel in Vrnjacka Banja, and the Grand \& Spa Hotel in Kopaonik. For Serbia's national hotels, we collected primary data (through phone interviews with managers) and secondary data (through the analysis of the existing literature and data from their official websites). We selected hotels located in the leading city (Belgrade), spa (Vrnjačka Banja), and mountain (Kopaonik, Zlatibor) travel destinations of Serbia.

\section{Research results}

\subsection{Staff training and development in the international hotel chains}

\subsubsection{Inter Continental Hotel Group (IHG)}

InterContinental Hotel Group (IHG) operates in more than 100 countries worldwide with 17 brands. More than 400.000 employees work in over 5,900 IHG hotels. ${ }^{41}$ This group pays a lot of attention to his employees and their careers. The group provides comprehensive "five-star" training for all newly recruited staff. The main goal of the "five-star" training is to help the employees to be the best from the first day of his work in IHG. Training courses is adapted so employees can learn through multiple ways: online learning or learning through work

\footnotetext{
$40 \quad$ Milićević Snežana, Štetić Snežana. (2017).

41 IHG. (2020): About us. https://www.ihgplc.com/en/about-us, April 20, 2020.
} 
experience, such as job rotation or learning from others ways. In the training process employees learn from experience (challenging projects, secondments, job rotations, extra responsibilities), relationships (line manager coaching, mentors, networking, shadowing) and from formal learning (online learning, programmes, conferences, articles/ ase studies). In the whole process, learning from experience is represented by 70 percent, learning from relationships by 20 percent and formal learning by 10 percent. ${ }^{42}$

Each year, IHG runs an initiative called RISE - a program designed to encourage women to step up and establish the skills needed to take on leadership roles in their future. On the program, each of the 28 selected participants are partnered with a female senior leader who becomes their mentor, with the aim to grow them into future General Managers. The other development program of this corporation is the „Future Leaders “ program. Anyone in IHG who wants to become a leader in the future has the opportunity to access the MyLearning online platform. On this platform employees can find hundreds of trainings. They are practically available for employees at their fingertips. During their free time, employees can explore various career development courses. ${ }^{43}$ Minh, Nguyen \& Duc (2019) ${ }^{44}$ wrote about employee training and development of the IHG in Vietnam. They say that for employees in the food and beverage sector there is a food standards course. The training is adapted for everyone who is working in food and beverage sector. Part of the training is leader training program. With this training program various modules and topics are covered, such as how to plan ahead, how to develop your team, how to lead others and how to create change.

\subsubsection{Marriott International}

Marriott International group has 30 brands and over 7000 properties in 131 countries worldwide. ${ }^{45}$ At year-end 2019, this group had approximately 174,000 employees. ${ }^{46}$ This group offers its employees a global leadership development program called „VOYAGE “ which lasts from 12 to 18 months. This Marriott International's development program this program relates to the field of leader-

$42 \quad$ IHG. (2020b): Early Careers. https://earlycareers.ihg.com/ec/en/home, April 20, 2020.

43 IHG. (2020a): From Front Office Assistant to Future Leader. https://careers.ihg.com/ihgstories/front-office-assistant-future-leader-achieving-dreams-ihg, April 20, 2020.

${ }^{44}$ Minh Nguyen Duc. (2019): „Training And Development At IHG: Becoming A Rising Star By Creating A Successful Food And Beverage Career In Vietnam. " https://earlycareers. ihg.com/ec/en/blog/training-and-development-at-ihg-becoming-a-rising-star-by-creating-a-successful-food-and-beverage-career-in-vietnam, April 20, 2020.

45 Marriott International. (2020): About us. https://www.marriott.com/marriott/aboutmarriott.mi, April 18, 2020.

46 Marriott International. (2020c): 2019 Annual Report. https://marriott.gcs-web.com/staticfiles/178683c9-c9d9-47b0-b115-726588f43130, April 18, 2020. 
ship. This program offering resources and support for future leaders of the company across Marriott's hotel brands. The main advantages of the program are: ${ }^{47}$ - The application of practical and virtual training in many disciplines (Accounting \& Finance, Culinary, Engineering, Event Management, Food \& Beverage, Human Resources, Revenue Management, Rooms Operations).

- Employees are provided with training through job rotation and cooperation with senior leaders

- Network with colleagues on global levels through social collaboration tools

- Engage with Marriott senior leaders.

Another program that is applied is the internship employees. This program includes a combination of on-the-job training and an introduction to the culture at Marriott International. Standard programs last 8-12 weeks and can extend to 12 months or longer in certain locations. The training includes focusing on various areas such as cooking, facility management, finance and accounting, human resources and many others. ${ }^{48}$ Since 2017 , more than 730,000 hotel workers have completed training on how to spot and respond to signs of human trafficking in our hotels. ${ }^{49}$

\subsubsection{Accor Hotels}

Accor hotels consists of a total of 30 brands with 5,000 hotels, 300,000 employees in 110 countries. ${ }^{50}$ In Accor hotels they are riding for development the potential of each talent by encouraging it lifelong learning through experience, training and mentoring. In 2018, 91\% of employees received training. At the same time Académie Accor program trained 1,000 certified internal trainers. Accor hotels offer their employees over 250 training modules. Some of these modules are offered in more than 20 languages and cover 75 countries. This group sets new standards in innovation as it offers employees training programs that increasingly include new technologies, such as e-learning modules, virtual classrooms and mobile applications. ${ }^{51}$

They provide learning experiences for all employees through the 5 regional academies and with their local hubs. Learning experiences can be on the job, in

\footnotetext{
$47 \quad$ Marriott International. (2020b): Voyage Global Leadership Development Program. https://university.marriott.com/post-graduates/, April 18, 2020.

48 Marriott International. (2020a): Marriott University Program. https:/university.marriott.com/internships/, April 18, 2020.

49 Marriott International. (2020c). April 18, 2020.

50 Accor hotels. (2020): “Accor Overview". https:/group.accor.com/en/group/who-we-are/accor-in-brief, April 21, 2020.

51 Accor hotels. 2020c. 2018 Registration Dokument. "Annual financial Report”. https://group.accor.com/en/Search/Search?query=training, April 21, 2020.
} 
classroom, digital or blended. ${ }^{52}$ In Accor hotels believe that apprenticeships and internships are very powerful ways to learn and training. work in partnership with a variety of schools and training centres. The aim is to provide the best and the most innovative training offer ${ }^{53}$ Employees also can learn and train its skills by using a mobile phone (by gamification, reverse learning, virtual reality, etc.). Learning must be fun, innovative, surprising. This way of learning in Accor is not a job requirement. It is an individual choice of all employees. ${ }^{54}$

\subsubsection{Hyatt}

Hyatt is a company with 20 premier brands and more than 900 hotel, allinclusive, and wellness resort properties. ${ }^{55}$ This group has more than 127,000 employees in 65 countries. ${ }^{56}$ Each Hyatt hotel conducts a variety of trainings with programs in the field of complaint handling, sales techniques, finance for staff in positions outside the finance and accounting sectors. Also, the following types of training are performed here: "Trainings the Trainers"(this training trains future or current class trainers and they are trained to transfer their knowledge to new employees, mainly those on the first line of service such as maids or waiters), "Service Excellence" (intended for employees who are in direct contact with the guest), „Smart Selling” (mandatory training for the sales department), „Leaderhip Series" (intended for management as well as employees who have the potential for advancement and further growth within the company). Most of these trainings take place at the hotel. Hyatt sends its employees abroad for training several times during the year. Within the training "General Orientation" (introductory training that must be passed by all new employees, mostly before starting work) there are a number of training models. They concern basic knowledge about working in a hotel. ${ }^{57}$

The Hyatt Group also organizes a summer program throughout the United States. This program is organized in areas such as culinary, events, food and

\footnotetext{
$52 \quad$ Accor hotels. (2020b): “Tailored Opportunities”. https://group.accor.com/en/careers/life-at-accor/tailored-opportunities, April 21, 2020).

53 Accor hotels. (2020a): "Join our teams". https:/group.accor.com/en/careers/join-a-leader/be-a-part-of-our-teams, April 21, 2020).

54 Accor hotels. (2020b). April 21, 2020.

55 HYATT. (2020): About Hyatt. https://about.hyatt.com/, April 15, 2020.

56 HYATT. (2020a): Careers. https://careers.hyatt.com/en-US/careers, April 15, 2020.

57 Aleksić Aleksandra. (2015): “Analogija obuke zaposlenih i zadovoljstva korisnika u hotelijerstvu”. Synthesis 2015 - International Scientific Conference of IT and Business-Related Research, Singidunum University, Belgrade, 504-507.
} 
beverage, facilities, finance, human resources, operations, revenue, rooms, sales, spa. Training participants get a chance to: ${ }^{58}$

- Hands-on learning in your area of concentration,

- Shadow any hotel department you are interested in,

- Participate in hotel meetings,

- Work side-by-side with hotel leaders.

There is also a program with a 40 year history of successfully cultivating industry leaders. The program lasts between 7 and 14 months. The participant passes the training with a mentor and gain exposure to each department in the hotel through a dedicated rotation. ${ }^{59}$ Another program of this corporation is a University program in Latin America and the Caribbean. The duration of this program is 12 months. Employees have the opportunity to: ${ }^{60}$

- Complete a 12-month program in food \& beverage or rooms,

- Receive guidance and support from your hotel leader mentor,

- Management of a project around business goals,

- Gain exposure to our Regional Corporate Office.

\subsection{Staff training and development in national hotels in Serbia}

\subsubsection{The Mona Hotel Management Company}

The Mona Hotel Management runs four objects in Serbia and one in Montenegro. They are: the Zlatibor Mona Hotel, Mona Plaza Belgrade, the Argo Garni Hotel in Belgrade, the Javor Hotel in Kušići, and Bella apartments in Budva. A total of 300 employees work in these objects. ${ }^{61}$

What's more, it's important to note that the Mona Hotel Management's HR has an extremely efficient selection process during which they choose employees with proper attitude, knowledge, and competencies. HR is highly dedicated to staff training and development which is evidenced by the fact that they had over 1,100 hours of trainings (courses, online trainings, educational and field trips) in 2019. The Mona Hotel Management's objects have various staff training and development programs. The training can encompass various job positions in the hotels, including front office, finance, up-selling, and similar. The programs

$58 \quad$ HYATT. (2020b): KICK START YOUR CAREER. An introduction to Hyatt's University

Programs, https://careers.hyatt.com/assets/documents/UNIVERSITY_PROGRAMS_

US.pdf, April 15, 2020.

$59 \quad$ HYATT. (2020b), April 15, 2020.

60 HYATT. (2020c): KICK START YOUR CAREER. An introduction to Hyatt's University Programs in Latin America and the Caribbean, https://careers.hyatt.com/assets/documents/UNIVERSITY_PROGRAMS_LAC.pdf, April 15, 2020.

61 Company Mona Hotel Management. (2020): Our facilities.

https://monahm.com, February 28, 2020. 
are usually internal, but there are also external training and development programs. Also, the actual training and development program is influenced by the availability and time of employees, and training dates need to be adjusted to the events in their hotels. ${ }^{62}$

One of the tasks of HR is to train employees in orientation, communication (both oral and written), handling of customer complaints, teamwork, mutual understanding, and creation of a pleasant work environment. By using the international standard of Train the Trainer, HR wants to form internal trainers that will train employees in individual departments. The training is done so that the trainer can learn the methodology, how to use various tools and to manage dynamic groups. After the end of the training, the trainers can provide lectures in the workplace. By having a manager or supervisor lead training programs, an employee learns the ropes in the workplace. All new employees go through the employee orientation programs. This is where new employees learn everything about the hotels, business, future projects, and meet other employees. New employees learn the ropes for one month. ${ }^{63}$

The Mona Hotel Management Company uses state-of-the-art information technology. Currently, it is developing an HR platform that will help the company efficiently manage human resource. Apart from the HR platform, all employees will have access to an e-learning platform. With the help of this platform, employees will be able to access content that will expand their knowledge and skills at any moment. The platform will include lectures, videos and audios, and articles that help employees learn something new in their or some other sphere of business. ${ }^{64}$

Training programs in hotels of the Mona Hotel Management include: ${ }^{65}$

- Traditional training methods.

- On-the-job training.

- Courses.

- Online platforms.

- Cross-training - The training of employees in a different department. The employee who wants to learn, expand their knowledge, and change job positions has the opportunity to learn the ropes in other departments. The employee undergoes this training after getting an approval from their manager and the department.

- $\quad$ Mentorship - A mentor facilitates this training. They are an expert who motivates and affects employee development through their advice and guidance.

62 Company Mona Hotel Management. (2020a): Personal interview with Human Resources Manager Marija Lekić, March 11, 2020.

63 Ibid.

64 Ibid.

65 Ibid. 
- Professional internship - Because of this program, the hotel is collaborating with faculties whose students are interns in the hotels of the Mona Hotel Management. Currently, the company does professional internships with the Faculty of Hotel Management and Tourism in Vrnjačka Banja and the College of Hotel Management in Belgrade.

- Dual education - This program was introduced in Zlatibor Mona in collaboration with the School of Tourism and Hospitality from Čajetina. The future plans are to introduce this program in Mona Plaza in Belgrade.

- Educational trips - Employees take part in fairs and conferences in the country and abroad.

- Scholarships - The hotel is investing in the future by providing scholarships to students. In this way, the youth is encouraged to choose the hospitality industry. Currently, the Mona Hotel Management's scholarship program includes several students of gastronomy.

\subsubsection{The Solaris Resort Hotel, Vrnjačka Banja}

The Solaris Resort Hotel is a part of tourism offer of Vrnjačka Banja. The hotel has penthouse apartments, lobby bar, two restaurants, two outdoor pools and one indoor saltwater pool, wellness spa spanning $1,000 \mathrm{~m} 2$, a conference hall with 200 seats, and a game room with two professional entertainers. ${ }^{66}$

The basic goal of training in the Solaris Resort Hotel is to develop employees' knowledge, skills, and competencies. This will directly affect customer satisfaction. The training process is carried out in the hotel, but sometimes somewhere else as well. Also, the training methods that are used are on-the-job (mentorship) and off-the-job training (seminars, fairs, educational trips). Usually, the training relies on the combination of various methods. Both new and existing employees can take part in the training. When a new employee is hired, the on boarding process commences and its duration varies. Namely, the duration depends on the department and complexity of the job position. For instance, this process in the sales, marketing, and front offices lasts for a month. In the food and beverage service, i.e. for those working as bartenders, waiters, and chefs, it lasts for ten days. Moreover, the highly qualified heads of departments are in charge of internal trainings. In addition, they hire external experts if there is a need for them. For instance, the hotel organizes the training for physical therapists working in its wellness spa. This training lasts for three days. The hotel hires experts in physical therapy and employees participate in the course. This particular training is performed when the hotel isn't overbooked. ${ }^{67}$

$66 \quad$ Solaris Resort Hotel. (2020): About us.

https://www.solarisresort.com/en/about-us/, March 31, 2020.

67 Solaris Resort Hotel. (2020a): Hotel internal documentation, April 1, 2020.

Vol. 18, № 3, 2021: 89-110 
However, the hotel doesn't only invest in the staff training programs for the lower-level positions. There's also training for managers from different departments. The managers visit seminars where they improve their knowledge and skills. In addition to this, the hotel also organized free English courses for all employees. They attended the classes in groups. Those working in managerial positions attended higher course levels, while maids, housekeepers, and handymen attended lower course levels. The employees also have a chance to get promoted and advance their careers. There are already examples where an employee was promoted from the bar to the wellness spa's front office, and ultimately to the main front office. Another example is that of a housekeeper who was promoted to the front office. ${ }^{68}$

\subsubsection{The Grand Hotel \& Spa, Kopaonik}

The Grand Hotel \& Spa in Kopaonik has four stars. For three decades, this company has been operating in the hospitality industry of Serbia. The hotel offers 201 rooms and apartments, and the Grand Oaza Spa \& and Wellness Center spanning $1,800 \mathrm{~m}^{2}$. The five conference halls are home to congresses, conferences, symposiums, and seminars. There's also room for sports and entertainment in the hotel as it has a sports venue, fitness center, and provides outdoor activities. The guests can choose from sightseeings, mountain biking, orienteering, archery, picnics, riding a quad bike, bowling, and other activities. ${ }^{69}$ During the tourist season, the hotel employs 150 people. ${ }^{70}$ The hotel is a part of the MK Group that does business in three key fields: agriculture, tourism, and banking. The Group formed the Talent Academy (MKademija). Of course, the Academy's goal is to train those employees the management recognizes as talents. It is aimed at employees working in all three fields of business. The employees in the Grand Hotel \& Spa in Kopaonik also have a chance to improve their existing competencies in the Academy. ${ }^{71}$

In the Grand \& Spa Hotel, all employees undergo trainings whose goal is to engage and motivate the staff. They analyze the employees' capabilities and create proper programs for both training and courses. The training within departments is done by the departmental trainers, but it's also common for the hotel to hire external associates to improve skills. Specific staff training and development methods in this hotel include the on-the-job training, job rotation, learning through work, and courses. The trainings are done in the workplace and there are general trainings (foreign languages, IT), professional trainings (improving

68 Ibid.

69 MK Group. (2020): MK Tourism. https://www.mkgroup.rs/mk-tourism, April 11, 2020.

70 Drašković Stefan. (2016): "Upravljanje ljudskim resursima u hotelu "Grand \& Spa" Kopaonik". Master thesis. Univezitet Singidunum.

71 MK Group. (2020a): Career. https://www.mkgroup.rs/career/?lang=en, April 11, 2020. 
the knowledge and skills for the job), and trainings that improve managerial skills (management of HR, stress, and communication). The hotel's management organizes language courses for employees, then health and safety courses, and similar. The employees can advance their careers. Namely, they can attend various courses and put their knowledge to work. A manager is in charge of the employee career development. ${ }^{72}$

\subsubsection{The Moskva Hotel, Belgrade}

The Moskva Hotel is the architectural gem of Belgrade. Opened in 1908, the hotel is now under state protection. This hotel offers 123 rooms, the Spa \& Wellness center, a la carte Tchaikovsky Restaurant and famous Moskva Caffe - Pastry Shopp, and four conference halls with the capacity for 220 people. $^{73}$

The Moskva Hotel determines the need for training and annual spending when it plans and examines its resources. In order to execute all tasks in this company, the hotel has determined which professional qualifications, trainings, knowledge, and experience a specific employee must possess. The executive selects candidates for a position according to their competencies for that job. Before independently taking on the job, an employee goes through a basic training for the quality management system and food safety for their position. Then, they also have lessons for fire safety, and occupational safety and health in the workplace. An employee's ability to perform the required activities is determined by their supervisor. To build and raise employee awareness of their role in assuring food quality and safety, there are a lot of trainings for employees and all departments according to the plan for the "P0-E3" program. The representative for Quality Management together with the leader of the NASSR team, managers, and heads of departments proposes this plan. In the end, the executive approves it. The form for the employee education plan contains a lot of data. For instance, you need to write in the date (i.e. the period), where the staff training will take place, the name of the training, the status of the training plan (planned/emergency), the realization status (realized/not realized), the date of realization, the trainer, materials, the signature of the head of the department who made the plan, and the signature of the representative for Quality Management. The hotel keeps records about the finished trainings. They include details about the lecturer, audience, subject, and the date of the training. This is all included in the "P0-E4" form, i.e. the form that proves the training has been done. This form has information such as the date (i.e. the period of the training), the subject, the lecturer, the contents, the first and last names of the students, and the signatures of the students, lecturer, and the representative for Quality Management. It is the

72 Drašković Stefan. (2016).

73 Moskva Hotel. (2020): About Hotel.

https://hotelmoskva.rs/en/hotel-en-us/, April 30, 2020. 
representative for quality management who keeps the assessment of the training's efficiency. Managers and the heads of departments periodically check the efficiency of the trainings, notifying the representative for Quality Management who then makes note of this in the Internal Staff Training Book. ${ }^{74}$

\section{Conclusion and Discussion}

The comparative analysis leads us to conclude that training and development are an important part of every business. When it comes to the training and development methods in national hotels in Serbia and international hotel chains, we could say that they mostly use on-the-job and off-the-job training methods. But it's more common for them to use a combination of various training methods. Even the conclusion of the research Martin-Ostrowski, Kolomitro and Lam $(2014)^{75}$ is that the trainers should use different training methods to fulfill the needs of the students.

The starting assumption of this paper was that international hotel chains have more advanced training and development programs than Serbia's national hotels. The accuracy of our assumption is proven by training and development programs like "Future Leaders" in the IHG (IHG, 2020a) ${ }^{76}$, postgraduate program for the leadership development "VOYAGE" in Marriott International (Marriott International, 2020a) ${ }^{77}$, the staff training with smartphones in the Accor Hotels (Accor, 2020a) $)^{78}$ and the college programs in Hyatt Group (HYATT, 2020b ${ }^{79}$.The programs in the Hyatt Group or the IHG entail the knowledge and skills acquisition as well as training the employees for higher positions. Companies often let employees decide whether they want to attend the training and development programs.

Serbia's national hotels also strive to keep up with the modern trends in the hospitality industry. Staff training is mostly done with the help of the same methods used in the international hotel chains. Positive examples from Serbia are the Talent Academy (MK Group, 2020a) ${ }^{80}$, the scholarships for students who might become their future staff, trainer development, online platforms for learning, and educational trips (Company Mona Hotel Management, 2020a) ${ }^{81}$, and

\footnotetext{
$74 \quad$ Moskva Hotel. (2020a): Hotel internal documentation, April 30, 2020.

75 Martin Ostrowski Barbara, Kolomitro Klodiana, Lam C. M. Tony. (2014). 11-35.

76 IHG. (2020a). April 20, 2020.

77 Marriott International. (2020a).April 18, 2020.

78 Accor hotels. (2020a). April 21, 2020.

79 HYATT. (2020b). April 15, 2020.

$80 \quad$ MK Group. (2020a). April 11, 2020.

81 Company Mona Hotel Management. (2020a).March 11, 2020.
} 
the free English language courses for all employees (Drašković, 2016; ${ }^{82}$ Solaris Resort Hotel, 2020a $\mathrm{a}^{83}$ ). The trainings are aimed at various fields. For instance, the Moskva Hotel has different trainings, ranging from quality management and food safety, to fire protection (Moskva Hotel, 2020a) ${ }^{84}$. In the hotels of the Mona Hotel Management (the Zlatibor Mona Hotel, Mona Plaza Belgrade, the Argo Garni Hotel Belgrade, and the Javor Hotel in Kušići), there are traditional training and development methods, but they are increasingly starting to use modern technology, i.e. online learning platforms (Company Mona Hotel Management, $2020 \mathrm{a}{ }^{85}$. In Serbia's national hotels, managers monitor employees and their abilities for further development. It's common for an employee on a lower-level position to become the head of a front office, restaurant, or some other department in the company. The development programs do exist in Serbia's national hotels, but they aren't as advanced as those in the international hotel chains. The hotels of the Mona Hotel Management follow in the footsteps of the international hotel chains when it comes to staff training and development (they organize trainings for departmental trainers, give scholarships for their future employees, and use an online learning platform).

The conclusion is that Serbia's national hotels have proper training programs, but they aren't as developed as those in the international hotel chains. To put it simply, the hospitality industry in Serbia needs to invest in human resources, and their knowledge and skills to be able to compete with others. ${ }^{86}$ Based on the research, our recommendation for Serbia's national hotels is that they follow the examples of the international hotel chains. They should adjust development programs of these chains to the existing work conditions, and professional and educational qualifications of employees in Serbia.

The contribution of this paper lays in the data that hotel managers can use to create their own innovative staff training and development programs. This paper has certain constraints which are the basis for any future research. Namely, the number of respondents, i.e. the number of national hotels compared here, should be increased. Also, the research only examined qualitative data on staff training and development in hotels. Quantitative data should be also researched by surveying the attitudes of managers and employees (for instance, how much do they invest in the staff training and development, how many hours do they devote to them) to get the complete picture about the differences in the stff training and development programs between two sides.

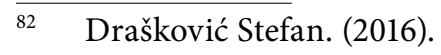

83 Solaris Resort Hotel. (2020a). April 1, 2020.

84 Moskva Hotel. (2020a). April 30, 2020.

85 Company Mona Hotel Management. (2020a). March 11, 2020.

86 Kordić Nikolina, Milićević Snežana. (2018): "Human resources in the hotel industry of Serbia" Hotel and Tourism Management, Vol. 6, No. 1, 93-103.
} 


\section{Literature:}

- Accor hotels. (2020): “Accor Overview”. https:/group.accor.com/en/group/ who-we-are/accor-in-brief, April 21, 2020.

- Accor hotels. (2020a): "Join our teams". https://group.accor.com/en/careers/ join-a-leader/be-a-part-of-our-teams, April 21, 2020.

- Accor hotels. (2020b): “Tailored Opportunities”. https://group.accor.com/en/ careers/life-at-accor/tailored-opportunities, April 21, 2020.

- Accor hotels. (2020c): 2018 Registration Dokument. "Annual financial Report". https://group.accor.com/en/Search/Search?query=training, April 21, 2020.

- Afaq Fakhar Ul, Yusoff Rosman, Khan Anwar, Azam Kamran, Thukiman Kassim. (2011): Employees' training and performance relationship in hospitality sector-A case of pearl continental hotel, Karachi, Pakistan. International Review of Business Research Papers, Vol. 7, No. 3, 149-158.

- Aleksić Aleksandra. (2015): "Analogija obuke zaposlenih i zadovoljstva korisnika u hotelijerstvu”. Synthesis 2015 - International Scientific Conference of IT and Business-Related Research, Singidunum University, Belgrade, 504-507.

- Ameeq-ul-Ameeq, Hanif F. Furqan. (2013): "Impact of Training on Employee's Development and Performance in Hotel Industry of Lahore, Pakistan." Journal of Business Studies Quarterly, Vol. 4, No. 4, 68-82.

- Amin Muslim, Aldakhil Abdullah Mohamed, Wu Chengzhong, Rezaei Sajadand, Cobanoglu Cihan. (2017): „The structural relationship between TQM, employee satisfaction and hotel performance", International Journal of Contemporary Hospitality Management, Vol. 29, No. 4, 1256-1278.

- Armah-Ansah, Quartey Rita. (2019): "Effects of Training on Employee Performance in Ga East Hotels". Acta Scientific Paediatrics, Vol. 2, No. 7, 02-07.

- Bourdoukou Aikaterini, Evangelia N. Markaki. (2020): „The Connection Between the Employee Satisfaction and the Learning and Development Process in the Greek Toursim Industry: A Qualitative Analysis." Education and Social Sciences Conference Business and Economics Conference, Barcelona, Spain, 10 February 2020. 41-50.

- Company Mona Hotel Management. (2020): “Our facilities”. https:// monahm.com, February 28, 2020.

- Company Mona Hotel Management. (2020a): Personal interview with Human Resources Manager Marija Lekić, March 11, 2020.

- Cranet. (2020): "Cranet survey on comparative human resource management - International Executive Report 2017.” https://www.fdv.uni-lj.si/docs/ default-source/cpocv-doc/cranet-international-report-2017.pdf?sfvrsn=4, April 11, 2020.

- Čerović Slobodan. (2019): Upravljanje ljudskim resursima u hotelijerstvu. Beograd: Univerzitet Singidunum. 
- Drašković Stefan. (2016): “Upravljanje ljudskim resursima u hotelu "Grand \& Spa” Kopaonik". Master thesis. Univezitet Singidunum.

- Dzhandzhugazova A. Elena, Zaitseva A. Nataliya, Larionova A. Anna., Pervunin, N. Sergey. (2015): “The Russian Hotel Market: condition and development under the crisis." Mediterranean Journal of Social Sciences, Vol. 6, No. 3-S5, 289-296.

- Đorđević-Boljanović Jelena. (2018): Menadžment ljudskih resursa. Beograd: Univerzitet Singidunum.

- Habib Ahsan, Shahadat Hossain, David Daniel Essien. (2016): „Assessing the Effect of Training on Employees' Performance in Nigeria Hotel Industry: A Case Study of Sheraton Hotel and Resorts Lagos." Singaporean Journal of Business, Economics and Management Studies, Vol. 51, No. 3785, 1-13.

- HYATT. (2020): “About Hyatt”. https://about.hyatt.com/, April 15, 2020.

- HYATT. (2020a): "Careers". https://careers.hyatt.com/en-US/careers, April $15,2020$.

- HYATT. (2020b): "KICK START YOUR CAREER. An introduction to Hyatt's University Programs”, https://careers.hyatt.com/assets/documents/ UNIVERSITY_PROGRAMS_US.pdf, April 15, 2020.

- HYATT. (2020c): "KICK START YOUR CAREER. An introduction to Hyatt's University Programs in Latin America and the Caribbean”, https:// careers.hyatt.com/assets/documents/UNIVERSITY_PROGRAMS_LAC. pdf, April 15, 2020.

- IHG. (2020): “About us". https://www.ihgplc.com/en/about-us, April 20, 2020.

- IHG. (2020a): "From Front Office Assistant to Future Leader". https:// careers.ihg.com/ihg-stories/front-office-assistant-future-leader-achievingdreams-ihg, April 20, 2020.

- IHG. (2020b): Early Careers. https://earlycareers.ihg.com/ec/en/home, April 20, 2020.

- Komenić Pavle, Vanda Bazdan, Besim Agušaj. „The organizational climate and employee turnover Intention in Dubrovnik hotels." RIThink Vol. 5, No. $1,7-14$.

- Kordić Nikolina, Milićević Snežana. (2018): "Human resources in the hotel industry of Serbia" Hotel and Tourism Management, Vol. 6, No. 1, 93-103.

- Lee C. Patrick, Bugler R. Martin. (2017): "Training practices in the Hong Kong hotel industry: Managerial and executive perspectives." Journal of Human Resources in Hospitality \& Tourism, Vol. 16, No. 1, 88-107.

- Marriott International. (2020): “About us". https://www.marriott.com/ marriott/aboutmarriott.mi, April 18, 2020.

- Marriott International. (2020a): “Marriott University Program”. https://university.marriott.com/internships/, April 18, 2020.

- Marriott International. (2020b): "Voyage Global Leadership Development Program”. https://university.marriott.com/post-graduates/, April 18, 2020. 
- Marriott International. (2020c): 2019 “Annual Report”. https://marriott.gcsweb.com/static-files/178683c9-c9d9-47b0-b115-726588f43130, April 18, 2020.

- Milić Zoran. (2011): Menadžment ljudskih resursa, Beograd: Visoka strukovna škola za preduzetništvo.

- Milićević Snežana, Štetić Snežana. (2017): Menadžment u turizmu, Vrnjačka Banja: Fakultet za hotelijerstvo i turizam.

- Minh Nguyen Duc. (2019): „Training And Development At IHG: Becoming A Rising Star By Creating A Successful Food And Beverage Career In Vietnam. “ https://earlycareers.ihg.com/ec/en/blog/training-and-developmentat-ihg-becoming-a-rising-star-by-creating-a-successful-food-and-beveragecareer-in-vietnam, April 20, 2020.

- MK Group. (2020): “MK Tourism”. https://www.mkgroup.rs/mk-tourism, April 11, 2020.

- MK Group. (2020a): “Career”. https://www.mkgroup.rs/career/?lang=en, April 11, 2020.

- Mohan Ajeet Kumar Lal, A. Dharmaraj. (2015): „Training-an imperative hr practice in hotel industry." International Journal of Physical and Social Sciences, Vol. 5, No. 12, 96-103.

- Moskva Hotel. (2020): "About Hote"l. https://hotelmoskva.rs/en/hotel-enus/, April 30, 2020.

- Moskva Hotel. (2020a): Hotel internal documentation, April 30, 2020.

- Muthukumar E., Vidhya Shanmugam, Babu Jiby. (2016): „Effectiveness \& evaluation of training and development programme in Pollachi hotels - a case study." Journal of Arts, Science \& Commerce, VII - Vol. 3, No. 2, 1-7.

- Olabinjo M.A., Ezenagu Ngozi, Esoso, J. (2020): Appraisal of hospitality industry's response to human resource management issues and challenges: Evidence from Lagos, Nigeria African Journal of Hospitality, Tourism and Leisure, Vol. 9, No. 2, 1-19.

- Martin Ostrowski Barbara, Kolomitro Klodiana, Lam C. M. Tony. (2014): „Training methods: A review and analysis. "Human Resource Development Review, Vol. 13, No. 1, 11-35.

- Perović J. Milan. (2007): “Obuka i osposobljavanje u funkciji integrisanog sistema menadžmenta.” 34. Nacionalna konferencija o kvalitetu, Kragujevac, 08. - 11. maj, uvodni referat.

- Poór József, Slavić Agneš, Katalin Tóth, Berber Nemanja, Kerekes Kinga, Karoliny Zsuzsa. (2020): „Benchmarking in human resource management in focus of Central and Eastern Europe in the light of CRANET research. "Strategic Management, Vol. 25, No. 1, 21-28.

- Prasanth S. (2015): „Training and Development in Hotel Industry.” Shanlax International Journal of Management, Vol. 3, No. 1, 27-34.

- Rakičević Gabriela. (2000): „Obrazovanje - investicija u ljudski kapital. Turizam, No. 4, 41-43. 
- Rathore Pradyuman Singh. 2017. „Significance of training and hospitality skills for hotel employees. "International Journal of Engineering and Management Research (IJEMR), Vol. 7, No. 3, 53-56.

- Ristić Miroslava, Radovanović Ivica, Tadić Aleksandar. (2011): “Obuka zaposlenih u sistemu e-učenja."Inovacije u nastavi - časopis za savremenu nastavu, Vol. 24, No. 3, 74-85.

- Savović Slađana. (2006): "Značaj obuke i razvoja kadrova u ostvarivanju konkurentske prednosti preduzeća.”Ekonomski horizonti, Vol. 8, No. 1-2, 49-58.

- Slavić Agneš. (2005): "Obuka zaposlenih - značaj i uticaj na postizanje strategijskih ciljeva preduzeća.” Strategijski menadžment,” Vol. 10, No. 3, 29-34.

- Slavković Ana, Slavković Vukan. (2019): "The importance of training in contemporary organizations." Hotel and Tourism Management, Vol. 7, No. 2, $115-125$.

- Solaris Resort Hotel. (2020): “About us”. https://www.solarisresort.com/en/ about-us/, March 31, 2020.

- Solaris Resort Hotel. (2020a): Hotel internal documentation, April 1, 2020.

- Starc Jasmina, Rodica Barbara, Konda Iva. (2014): “Training and Educating Managers in Tourism." Hotel and Tourism Management, Vol. 2, No. 2, 7-21.

- Tošović-Stevanović Aleksandra, Ana Jurčić, Mihajlo Rabrenović. (2017): „Kulturološki aspekti menadžmenta i njihov uticaj na konkurentnost zemalja “. Megatrend Review, Vol. 14, No. 3, 149-164.

- Vasanthi S., Basariya S. Rabiyathul. (2019): "On the job training implementation and its benefits." IJRAR, Vol. 6, No. 1, 210-215.

- Vukonjanski Igor. (2019): Significance and successful training of persons in public administration of selected lands. Megatrend revija, Vol. 16, No. 3, 115-131.

- Živković Radmila, Aleksić Ana, Gajić Jelena. (2014): “Razvijanje kompetencija zaposlenih u hotelijerstvu." HR konferencija: Upravljanje kvalitetom ljudskih resursa - savremeni trendovi, Beograd, 23. oktobar, 109-116. 


\title{
OBUKA I USAVRŠAVANJE KADROVA: UPOREDNA ANALIZA NACIONALNIH HOTELA U SRBIJI I MEĐUNARODNIH HOTELSKIH LANACA
}

\begin{abstract}
Abstrakt: Posedovanje kvalifikovane i obučene radne snage imperativ je za poslovanje u hotelijerstvu i turističkoj industriji. Kompanije treba da pokažu da im je stalo do svojih zaposlenih pružajući im mogućnosti za napredovanjem i usavršavanjem. Cilj ovog rada je uporediti programe obuke i usavršavanja kadrova u nacionalnim hotelima u Srbiji sa programima medunarodnih hotelskih lanaca. Da bismo postigli unapred definisani cilj, koristili smo metod uporedne analize. Podaci za analizu prikupljeni su istraživanjem postojeće literature, zvaničnih veb sajtova hotela $i$ intervjuisanjem menadžera $u$ nacionalnim hotelima u Srbiji. Rezultati pokazuju da su programi obuke i usavršavanja kadrova napredniji u međunarodnim hotelskim lancima. Menadžment u nacionalnim hotelima u Srbiji odlučan je da sledi različite programe obuke i usavršavanja kadrova. Međutim, trebalo bi da ulažu više u uspostavljanje više programa, posebno onih usmerenih na razvoj njihovog osoblja, koje mogu kopirati iz međunarodnih hotelskih lanaca. Rezultati ovog istraživanja mogu biti korisni hotelskim menadžerima u procesu stvaranja sopstvenih inovativnih programa obuke i usavršavanja kadrova.
\end{abstract}

Ključne reči: ljudski resursi, obuka i usavršavanje, uporedna analiza, nacionalni hoteli u Srbiji, međunarodni hotelski lanci.

**** The paper is a result of research within the projects 179066 and III 46006, funded by the Ministry of Education, Science and Technological Development of the Republic of Serbia. 